\title{
ANALISIS TARGET \& REALISASI TERHADAP BEBERAPA JENIS PAJAK DI KABUPATEN PATI JAWA TENGAH
}

\author{
Muhyiddin Zainul Arifin \\ Dosen pada Jurusan Sistem Informasi dan Teknik Informatika \\ STMIK Bahrul Ulum, Jombang \\ hhtp//www.stmikbu.ac.id Email:stmikbu@telkom.net
}

\begin{abstract}
Abstrak
Untuk meningkatkan kemandirian pertumbuhan ekonomi Daerah. Maka Pemerintah Daerah Pati harus berupaya secara optimal bagaimana meningkatkan pertumbuhan ekonomi untuk meningkatkan PAD melalui komponen penerimaan pajak daerah berWilayah konsumsi yang berhubungan dengan pertumbuhan ekonomi.

Penelitian ini dilakukan pada bagian pengelolaan PBB sektor perdesaan dan perkotaan di Kabupaten Pati serta beberapa instansi terkait. Melihat demikian luasnya permasalahan yang ada, maka sasaran pengamatan dalam penelitian ini akan difokuskan pada pengelola PBB dan para pejabat di Kantor Dispenda Kabupaten Pati.

Data yang diperoleh dalam penelitian ini akan dianalisis dengan menggunakan analisis regresi sederhana dengan bantuan program eviews, elastis pajak daerah, analisis MRP melalui dua pendekatan yaitu rasio pertumbuhan wilayah referensi (RPR) dan rasio pertumbuhan wilayah studi (RPS), analisis location quotient (LQ), dan analisis overlay.

Hasil penelitian menunjukkan bahwa tingkat pertumbuhan penerimaan PBB sektor perdesaan dan perkotaan di Kabupaten Pati selama periode 2000/2001-2004/2005 berfluktuatif. Terlihat bahwa pada periode 2000-2004 mengalami penurunan dari tahun sebelumnya sebesar Rp491.594.820, atau turun sebesar 10,73\%, kemudian periode 2000/2001 mengalami kenaikan dari tahun sebelumnya sebesar Rp366.735.698 atau naik sebesar 8,96\%, pada periode 2004/2005 terjadi penurunan sebesar Rp146.491.658 atau berkurang 3,30\%, selanjutnya pada periode 2001/2002 terjadi kenaikan sebesar Rp258.142.522 atau naik 5,6\% sehingga rata-rata pertumbuhan sel9ma periode pengamatan sebesar $1,78 \%$. Demikian pula halnya dengan wajib pajak yang juga mengalami fluktuatif dengan rata-rata pertumbuhan $0,50 \%$.
\end{abstract}

Kata kunci : analisis MRP, analisis Location quotient, analisis overlay.

\section{Pendahuluan}

Pengembangan dalam tiga dasawarsa di negara sedang berkembang menunjukkan bahwa yang terjadi adalah rakyat dilapisan bawah tidak senantiasa dapat menikmati cucuran hasil pembangunan yang diharapkan, bahwa strategi pembangunan yang terlalu "GNPOrinted" tidak memberikan pemecahan mengenai masalah kemiskinan (keterbelakangan).

Perubahan politik akhir-akhir ini nampaknya menciptakan peluang-peluang bagi kehidupan sosial ekonomi. Hal tersebut setidaknya tercermin dari lahirnya paket perundang yang terdiri dari Undang-Undang nomor 22 tahun 1999 tentang pemerintahan daerah dan Undang-Undang nomor 25 tahun 1999 tentang perimbangan keuangan antara pemerintah pusat dan daerah. Garis besar yang ingin dicapai adalah motivasi dan komitmen untuk memperbaiki kesalahan-kesalahan struktural, beragam distorsi dan pelanggaran hukum, sementara ruang lingkup (dan harapan) spesifik yang hendak dituju adalah mengalirnya investasi efektif, bergairahnya aktivitas perekonomian, dan meningkatnya kesejahteraan diseluruh penjuru wilayah dengan didukung oleh good governance (Nugroho, 2000:103).

Berdasarkan fenomena yang telah dipaparkan diatas, maka penulis mengidentifikasi permasalahannya terkait dengan masalah yang fokusnya terletak pada PAD yang dimiliki Kabupaten Pati masih rendah. 
Hal ini meyebabkan penerimaan yang dibutuhkan untuk membiayai pembangunan masih sangat tergantung pada penerimaan yang bersumber dari sumbangan dan bantuan pemerintahan pusat atau Propinsi. Oleh karena itu untuk meningkatkan kemandirian pertumbuhan ekonomi Daerah. Maka Pemerintah Daerah Pati harus berupaya secara optimal bagaimana meningkatkan pertumbuhan ekonomi untuk meningkatkan PAD melalui komponen penerimaan pajak daerah berWilayah konsumsi yang berhubungan dengan pertumbuhan ekonomi. Dari penjelasan ini kiranya perlu untuk melakukan penelitian dengan Judul "Analisis Target \& Realisasi Terhadap Beberapa Jenis Pajak di Kabupaten Pati Jawa Tengah".

Berdasarkan latar belakang masalah yang telah diuraikan diatas maka dapat di kemukakan permasalahan sebagai berikut :

"Bagaimana Kinerja antara Target dan Realisasi beberapa Jenis pajak Daerah Kabupaten Pati ?"

Dari rumusan masalah yang telah dikemukakan diatas, tujuan yang ingin dicapai dalam penelitian ini adalah :

"Untuk Mengetahui Kinerja antara Target dan Realisasi beberapa jenis pajak Daerah Kabupaten Pati” berikut:

Hasil penelitian ini diharapkan dapat berguna dan memberikan nilai manfaat sebagai

"Memberikan sumbangan pemikiran pada para pengambilan keputusan dalam usaha peningkatan PAD melalui komponen beberapa jenis pajak yang pada akhirnya bermuara sebagai penunjang pertumbuhan ekonomi Daerah tanpa menunggu kucuran dana dari pusat"

\section{Rancangan Penelitian dan Tehnik Analisis Data}

Berdasarkan tujuan penelitian yang telah ditetapkan, maka jenis penelitian ini adalah penelitian Terapan. Jika ditinjau dari cara atau metode untuk mendapatkan data maka penelitian ini masuk dalam jenis penelitian Police Research.

Penelitian ini dilakukan pada bagian pengelolaan PBB sektor perdesaan dan perkotaan di Kabupaten Pati serta beberapa instansi terkait. Melihat demikian luasnya permasalahan yang ada, maka sasaran pengamatan dalam penelitian ini akan difokuskan pada pengelola PBB dan para pejabat di Kantor Dispenda Kabupaten Pati.

Variabel-variabel yang diamati dalam penelitian ini dapat didefinisikan sebagai berikut:

1. Pajak Bumi dan Bangunan adalah merupakan salah satu pajak pusat yang dikenakan atas bumi dan/atau bangunan yang diatur berdasarkan Undang-undang nomor 12 tahun 1985.

2. Bumi adalah permukaan bumi dan tubuh bumi yang ada di bawahnya;

3. Bangunan adalah konstruksi teknis yang di tanam atau dilekatkan secara tetap pada tanah dan/atau perairan;

4. Nilai Jual Obyek Pajak adalah harga rata-rata yang diperoleh dari transaksi jual beli yang terjadi secara wajar.

5. Tarif pajak yang dikenakan atas obyek pajak adalah sebesar 0,5\% (UU No. 12 tahun 1985);

6. Dasar perhitungan pajak adalah Nilai Jual Kena Pajak yang ditetapkan serendahrendahnya $20 \%$ dan setinggi-tingginya $100 \%$ dari Nilai Jual Obyek Pajak.

Dalam pengumpulan data dan informasi yang berkaitan dengan pengelolaan PBB sektor perdesaan dan perkotaan di Kabupaten Pati secara efektif melalui kegiatan sebagai berikut.

1. Penelitian kepustakaan (library research) yaitu dengan mempelajari literatur yang terdiri dari buku-buku literatur, hasil penelitian, jurnal, laporan berkala serta dokumen failnya yang berhubungan dengan obyek pembahasan dalam penelitian ini. 
2. Penelitian lapangan (field research) yaitu melakukan penelitian lapangan dan wawancara dengan pengelola PBB pada para pejabat di Kantor Dinas.

Data yang diperoleh dalam penelitian ini akan dianalisis dengan menggunakan analisis regresi sederhana dengan bantuan program eviews, elastis pajak daerah, analisis MRP melalui dua pendekatan yaitu rasio pertumbuhan wilayah referensi (RPR) dan rasio pertumbuhan wilayah studi (RPS), analisis location quotient (LQ), dan analisis overlay.

Penelitian ini bertujuan untuk menguji pertumbuhan ekonomi terhadap peningkatan penerimaan PAD melalui komponen pajak daerah berWilayah konsumsi, dan mengidentifikasi sektor Wilayah atau andalan yang dapat dikembangkan yang menekankan kepada struktur ekonomi berdasarkan kriteria pertumbuhan dan kontribusi.

Untuk dapat mencapai tujuan dimaksud maka akan digunakan alat-alat model perhitungan sebagai berikut :

1. Pengujian terhadap pengaruh PDRB terhadap peningkatan penerimaan pajak daerah berWilayah konsumsi akan dilakukan dengan elastisitas. Rumus elastisitas pajak daerah terhadap PDRB sebagai berikut (lihat Parkin dan Bade, 1992 :117).

$$
\begin{aligned}
& E=\frac{g_{i}}{g_{y}} \\
& \text { dimana: } \\
& \mathrm{E}=\text { elastisitas pajak daerah terhadap PDRB, } \\
& \mathrm{g}_{\mathrm{i}} \quad \text { = rata-rata laju pertumbuhan pajak daerah. } \\
& \mathrm{g}_{\mathrm{y}} \quad=\text { rata-rata laju pertumbuhan PDRB. }
\end{aligned}
$$

2. Mengidentifikasi sektor Wilayah atau andalan yang dapat di kembangkan dalam rangka peningkatan PAD yang berasal dari pajak daerah.

Untuk mengetahui ada tidaknya keunggulan suatu sektor pada suatu wilayah, maka dapat dilakukan suatu pengkajian atas kegiatan sektor yang dimaksud berdasarkan rasio

kontribusi dan pertumbuhannya dengan menggunakan suatu alat yang dinamakan model rasio pertumbuhan (MRP), location quotient (LQ), dan analisis overlay (Yusuf, 2000: 26-30).

a. Model Rasio Pertumbuhan (MRP)

$$
\begin{aligned}
& R P R=\frac{\left(\Delta E i R / E i R_{(t)}\right)}{\left(\Delta E R / E R_{(t)}\right)} . \\
& R P R=\frac{\left(\Delta E_{i j} / E i_{(t)}\right)}{\left(\Delta E_{i R} / E i R_{(t)}\right)} .
\end{aligned}
$$

dimana:

$\Delta \mathrm{E}_{\mathrm{iR}}=\mathrm{EIR}_{(\mathrm{t}+\mathrm{n})}-\mathrm{EiR}_{(\mathrm{t})}$

$\Delta \mathrm{ER}=\mathrm{ER}_{(\mathrm{t}+\mathrm{n})}-\mathrm{ER}_{(\mathrm{t})}$

Keterangan:

$\Delta \mathrm{E}_{\mathrm{iR}} \quad=$ Perubahan pendapatan $(\mathrm{PDRB})$ soktor I di wilayah referensi pada periode waktu $\mathrm{t}$ dan $\mathrm{t}+\mathrm{n}$,

$\mathrm{n}=$ Jumlah tahun antara dua periode,

$\Delta \mathrm{E}_{\mathrm{R}} \quad=$ Perubahan pendapatan (PDRB) total di wilayah referensi,

$\Delta \mathrm{E}_{\mathrm{ij}} \quad=$ Perubahan pendapatan (PDRB) total di wilayah studi,

$\mathrm{E}_{\mathrm{ij}}=$ Pendapatan (PDRB) sektor I di wilayah studi,

$\mathrm{E}_{\mathrm{R}}=$ Pendapatan $(\mathrm{PDRB})$ total di wilayah referensi. 
location quotients analysis

Perhitungan nilai LQ menggunakan rumus sebagai berikut (lihat Arsyad, 1997 : 291). $L Q=\frac{\left(X_{i j} / X_{J}\right)}{(X i R / X R)}$

di mana :

LQ = Sektor Wilayah (keuangan komperatif) di wilayah studi,

$\mathrm{Xij} \quad=$ PDRB sektor i di wilayah studi,

$\mathrm{Xj} \quad=$ Total PDRB diwilayah referensi,

$\mathrm{XiR}=$ PDRB sektor I di wilayah referensi.

$\mathrm{XR}=$ total PDRB diwilayah referensi.

c. Overlay analysis (NO)

Analisis Overlay dimaksudkan untuk melihat deskripsi kegiatan ekonomi yang potensial berdasarkan kriteria MRP dan LQ. Berdasarkan deskripsi tersebut ada empat kemugkinan yaitu: (1) MRP (+) dan LQ (+) menunjukkan suatu sektor yang sangat dominan baik pertumbuhan maupun kontribusi, (2) MRP (+) dan LQ (-) menunjukkan suatu sektor yang pertumbuhannya dominan tetapi kontribusinya kecil, (3) MRP (-) dan LQ (+) menunjukkan suatu sektor yang pertumbuhannya kecil tetapi kontribusinya besar, (4) MRP (-) dan LQ (-) menunjukkan bahwa suatu sektor yang tidak potensial baik dari kriteria pertumbuhan maupun kriteria kontribusi.

\section{Hasil Analisis dan Pembahasan}

\section{a. Perkembangan Data Variabel dan Hubungannya}

Dari hasil penelitian lapangan, diperoleh gambaran perkembangan masing-masing variabel yang diteliti. Variabel yang diamati adalah pertumbuhan, kontribusi, potensi dan proyeksi PBB di Kabupaten Pati.

Perkembangan pertumbuhan penerimaan PBB secara umum di tunjukan (gambar 1) Tampak adanya kecenderungan pertumbuhan yang terus meningkat dari tahun 2000/2001 peningkatan secara tajam terjadi pada tahun 2004/2005. Hal ini menunjukkan bahwa pertumbuhan yang nampaknya tinggi sebenarnya merupakan penambahan obyek/subyek pajak baru.

Gambar 1 memberikan gambaran mengenai fluktuasi yang terjadi pada kontribusi PBB terhadap APBD Kabupaten Pati tahun 2000/2001-2004/2005. Dalam gambar jelas terlihat bahwa tahun 2004/2005 terjadi peningkatan kontribusi PBB. Berkaitan dengan penerimaan $\mathrm{PBB}$ sektor perdesaan dan perkotaan pada tahun anggaran tersebut meningkat, sedangkan realisasi penerimaan APBD terjadi penurunan.

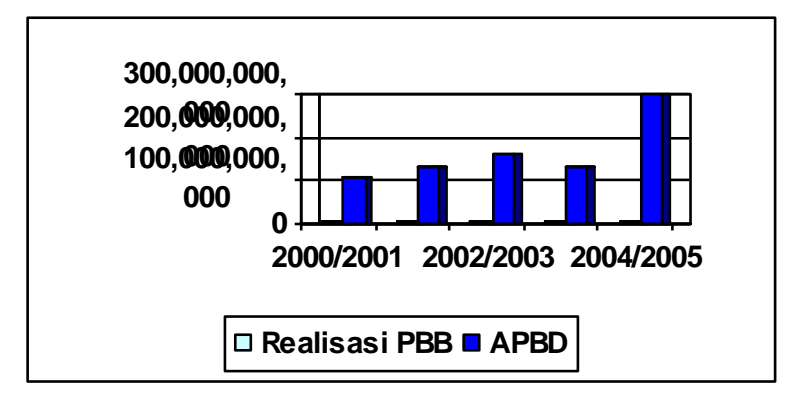

Gambar 1. Kontribusi PBB Sektor Perdesaan dan Perkotaan Terhadap APBD

Kabupaten Pati, 2000/2001-2004/2005 
Gambar 1 menunjukkan perkembangan potensi dan proyeksi PBB berdasarkan ketetapan KP PBB dengan potensi dan proyeksi hasil pengamatan dari 3 tahun berurut-urut trennya mengalami kecenderungan yang terus meningkat karena penentuan klasifikasi yang meningkat bersamaan dengan naiknya NJOP TKP sebesar Rp12.000.000.

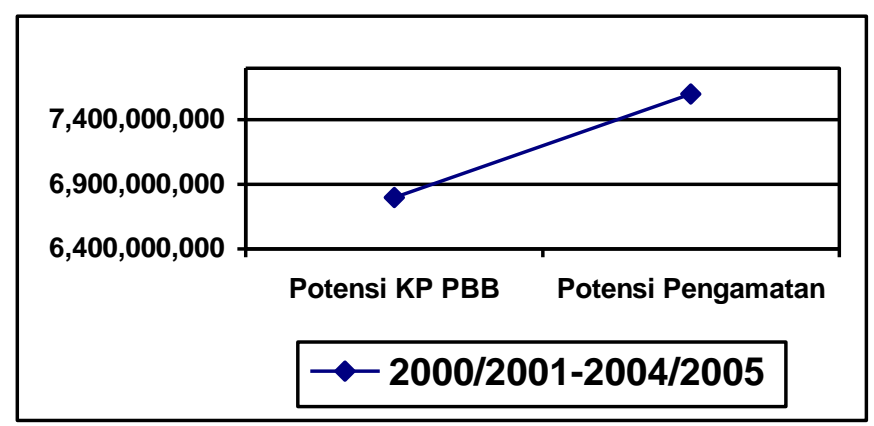

Gambar 2. Perbandingan Potensi KP P88 dan Potensi Pengamatan

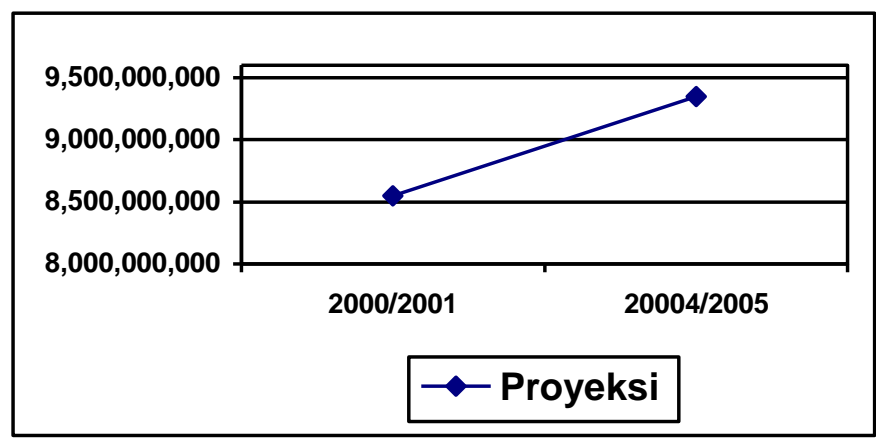

Gambar 3 Perbandingan Proyeksi, 2000/2001 dan 2004/2005

Seperti yang telah di kemukakan pada bab sebelumnya bahwa penentuan besarnya potensi penerimaan PBB sektor perdesaan dan perkotaan di Kabupaten Pati cenderung didominasi oleh KP PBB, sehingga data untuk perhitungan potensi PBB sektor perdesaan dan perkotaan diperoleh dari KP PBB sebagaimana tersebut pada (tabel 3) berikut:

Tabel 3. Potensi dan Target Penerimaan PBB Sektor Perdesaan dan Perkotaan di Kabupaten Pati, 2000/2001-2005

\begin{tabular}{|c|c|c|c|c|c|c|}
\hline \multirow{2}{*}{ No. } & \multirow{2}{*}{$\begin{array}{c}\text { Tahun } \\
\text { Anggaran }\end{array}$} & $\begin{array}{c}\text { Potensi } \\
\text { Penerimaan }\end{array}$ & \multicolumn{2}{|c|}{ Target Penerimaan } & \multicolumn{2}{|c|}{ Realisasi Penerimaan } \\
\cline { 3 - 7 } & & $(\mathrm{Rp})$ & $(\mathrm{Rp})$ & $(\%)$ & $(\mathrm{Rp})$ & \\
\hline 1 & 2 & 3 & 4 & $5=4: 3$ & 6 & $7=6: 3$ \\
\hline 1 & $2000 / 2001$ & $5.835 .021,314$ & 4.520 .333 .302 & 77,47 & $4.582 .441,614$ & 78,53 \\
\hline 2 & $2001 / 2002$ & 5.944 .365 .146 & $4,614.774 .000$ & 77,63 & 4.090 .846 .794 & 68,8 \\
\hline 3 & $2002 / 2003$ & 6.082 .629 .540 & 4.630 .000 .000 & 76,19 & 4.457 .582 .492 & 73,28 \\
\hline 4 & $2003 / 2004$ & 6.293 .824 .110 & 4.700 .000 .000 & 74,68 & 4.604 .074 .150 & 73,15 \\
\hline 5 & $2004 / 2005$ & 6.789 .079 .173 & 5.702 .000 .000 & 83,99 & 4.862 .216 .672 & 71,62 \\
\hline & Rata-rata & 6.188 .983 .856 & 4.833 .421 .480 & 78,10 & 4.639 .432 .344 & 73,08 \\
\hline
\end{tabular}

Sumber: - KP PBB Kabupaten Pati data potensi, beberapa terbitan (data diolah).

- Kantor Dispenda Kabupaten Pati data realisasi, beberapa terbitan (data diolah). 
Di Kabupaten Pati luas bumi di perdesaan yang dikenakan PBB rata-rata $15 \mathrm{~m}$ x 35m $=525 \mathrm{~m} 2$ dan apabila dilihat dari penentuan klasifikasi dan besarnya NJOP sebagai dasar pengenaan Pajak Bumi dan Bangunan untuk sektor perdesaan di Kabupaten Pati, dapat dilihat pada (tabel 4) berikut :

Tabel 4. Klasifikasi dan Besarnya NJOP Bumi Sektor Perdesaandi Kabupaten Pati

\begin{tabular}{|c|c|c|c|c|c|}
\hline Kelas & & \multicolumn{3}{|c|}{$\begin{array}{l}\text { Penggolongan Nilai Jual Bumi } \\
\qquad\left(\mathrm{Rp} / \mathrm{m}^{2}\right)\end{array}$} & $\begin{array}{c}\text { Ketentuan NJOP } \\
\text { Bumi } \\
\left(\mathrm{Rp} / \mathrm{m}^{2}\right)\end{array}$ \\
\hline 42 & $>$ & 1.400 & $\mathrm{~s} / \mathrm{d}$ & 2.000 & 1.700 \\
\hline 43 & $>$ & 1.500 & $\mathrm{~s} / \mathrm{d}$ & 1.400 & 1.200 \\
\hline 44 & $>$ & 760 & $\mathrm{~s} / \mathrm{d}$ & 1.050 & 910 \\
\hline 45 & $>$ & 550 & $\mathrm{~s} / \mathrm{d}$ & 760 & 660 \\
\hline 46 & $>$ & 410 & $s ! d$ & 550 & 480 \\
\hline 47 & $>$ & 310 & $\mathrm{~s} / \mathrm{d}$ & 410 & 350 \\
\hline
\end{tabular}

Sumber: KP-PBB Pati

Sedangkan luas bangunan rata-rata di perdesaan adalah $7 \mathrm{~m} \times 7 \mathrm{~m}=49 \mathrm{~m}^{2}$ dan apabila dilihat dari klasifikasi, penggolongan dan ketentuan Nilai Jual Bangunan dapat dilihat pada (tabel 5) berikut.

Tabel 5. Klasifikasi dan Besarnya NJOP BangunanSektor Perdesaan di Kabupaten

\begin{tabular}{|c|c|c|c|}
\hline Pati & $\begin{array}{c}\text { Penggolongan Nilai Jual } \\
\text { Bangunan } \\
\left(\mathrm{Rp} / \mathrm{m}^{2}\right)\end{array}$ & $\begin{array}{c}\text { Ketentuan } \\
\text { Nilai } \\
\text { Jual Bangunan } \\
\left(\mathrm{Rp} / \mathrm{m}^{2}\right)\end{array}$ & $\begin{array}{c}\text { Besarnya Pajak } \\
\text { Terhutang per } \mathrm{m}^{2} \\
\left(\mathrm{Rp} / \mathrm{m}^{2}\right)\end{array}$ \\
\hline 11 & $>194$. Q00 s/d 256.000 & 255.000 & 225 \\
12 & $>188.000$ s/d 194.000 & 191.000 & 191 \\
13 & $>136.000$ s/d 188.000 & 162.000 & 162 \\
14 & $>128.000$ s/d 136.000 & 132.000 & 132 \\
15 & $>104.000$ s/d 128.000 & 116.000 & 116 \\
\hline
\end{tabular}

Sumber: KP-PBB Pati

Karena Pajak Bumi dan Bangunan mulai I Januari 2005 NJOPTKP untuk setiap daerah ditetapkan setinggi-tingginya Rp12.00G.000 untuk tiap wajib pajak (WP). Apabila WP mempunyai lebih dari satu obyek pajak maka yang mendapatkan NJOPTKP hanya satu obyek, yaitu yang nilainya paling tinggi (brosur dari Departemen Keuangan RI Direktorat Jenderal Pajak Seri PBB-10). Dari klasifikasi di atas, baik untuk bumi maupun bangunan, kalau dihitung dengan mengambil kelas dengan harga rata-rata yang diperoleh dari transaksi jual beli yang terjadi secara wajar, untuk bumi menggunakan kelas 42 dan untuk bangunan menggunakan kelas 11, maka perhitungannya adalah:

\begin{tabular}{|c|c|c|}
\hline NJOP Bumi & $525 \mathrm{~m}^{2} \times \mathrm{Rp} 1.700$ & .500 \\
\hline NJOP Bangunan & $49 \mathrm{~m}^{2} \mathrm{x} \operatorname{Rp} 255.000 \ldots$ & 12.495 .000 \\
\hline \multicolumn{3}{|c|}{ NJOP sebagai dasar pengenaan } \\
\hline NJOP TKP. & $\ldots \ldots=\mathrm{Rp}$ & 12.000 .000 \\
\hline DP untuk & $\ldots .=\mathrm{Rp}$ & 1.387 .500 \\
\hline PBB Terhutang & x Rp 1.387.500,- & 1.387 .5 \\
\hline
\end{tabular}

Sedangkan untuk PBB sektor perkotaan untuk Kabupaten Pati keadaan tahun 2001, untuk bumi rata-rata luas $15 \mathrm{~m} \times 30 \mathrm{~m}=450 \mathrm{~m}$ dan apabila dilihat dari klasifikasi dan besarnya NJOP sebagai dasar pengenaan pajak berkisar antara kelas $36 \mathrm{~s} / \mathrm{d} 41$ untuk lebih jelasnya dapat dilihat pada (tabel 6) berikut : 
Tabel 6. Klasifikasi dan Besarnya NJOP Bangunan Sektor Perkotaan di Kabupaten Pati

\begin{tabular}{|c|c|c|c|}
\hline Kelas & $\begin{array}{c}\text { Penggolongan Nilai Jual } \\
\text { Bangunan }\left(\mathrm{Rp} / \mathrm{m}^{2}\right)\end{array}$ & $\begin{array}{c}\text { Ketentuan Nilai } \\
\text { Jual Bangunan } \\
\left(\mathrm{Rp} / \mathrm{m}^{2}\right)\end{array}$ & $\begin{array}{c}\text { Besarnya Pajak } \\
\text { Terhutang per }{ }^{2} \\
\left(\mathrm{Rp} / \mathrm{m}^{2}\right)\end{array}$ \\
\hline 09 & $>272.000 \mathrm{~s} / \mathrm{d} 348.000$ & 310.000 & 310 \\
\hline 10 & $>256.000 \mathrm{~s} / \mathrm{d} 272.000$ & 264.000 & 264 \\
\hline 11 & $>194.000 \mathrm{~s} / \mathrm{d} 256.000$ & 225.000 & 225 \\
\hline 12 & $>188.000 \mathrm{~s} / \mathrm{d} 194: 000$ & 191.000 & 191 \\
\hline 13 & $>136.000 \mathrm{~s} / \mathrm{d} 188.000$ & 162.000 & 162 \\
\hline 14 & $>128.000 \mathrm{~s} / \mathrm{d} 136.000$ & 132.000 & 132 \\
\hline
\end{tabular}

sumber: KP-PBB Pati

Dari klasifikasi di atas, baik untuk bumi maupun bangunan kalau dihitung dengan mengambil salah satu kelas misalnya untuk bumi menggunakan kelas 36 di mana NJOP bumi $\mathrm{Rp} 14.000 / \mathrm{m}^{2}$ dan untuk bangunan kelas 11 dengan Nilai Jual Bangunan Rp225.000/m2 maka hasil perhitungannya adalah:

\begin{tabular}{|c|c|}
\hline $450 \mathrm{~m}^{2} \times \mathrm{Rp} 14,000$. & 6.300 .000 \\
\hline $54 \mathrm{~m}^{2} \times \mathrm{Rp} 225.000$. & .000 \\
\hline NJOP sebagai dasar pengenaan pajak & 0.000 \\
\hline NJOPTKP & 12.000 .000 \\
\hline NJOP un & 6.450 .000 \\
\hline PBB Terhutang $0,5 \% \times 20 \% \times 6.450 .000$ & 6.450 \\
\hline
\end{tabular}

Potensi PBB sektor perdesaan dan perkotaan perlu,dianalisis dengan metode faktorial (Mardiasmo dan Makhfatih, 2000), yaitu memasukkan, beberapa variabel yang berhubungan secara kausalitas dengan penerimaan PBB. Dalam menganalisis potensi PBB dilakukan kajian terhadap semua hal yang berkaitan dengan PBB, untuk selanjutnya dibuat proyeksi PBB yang merefleksikan; (i) pengaruh dari variabelvariabel yang "tidak dapat dikendalikan" seperti pertumbuhan penduduk, laju inflasi, dan (ii) hasil dari kegiatan-kegiatan memperluas cakupan. Variabel-variabel yang dapat mempengaruhi besarnya potensi PBB.

Setelah mengetahui Perkembangan Data Variabel, maka diperlukan informasi mengenai hubungan variabel-variabel. Hubungan tersebut bisa dilihat dari gambar berikut :

Hubungan antar Variabel

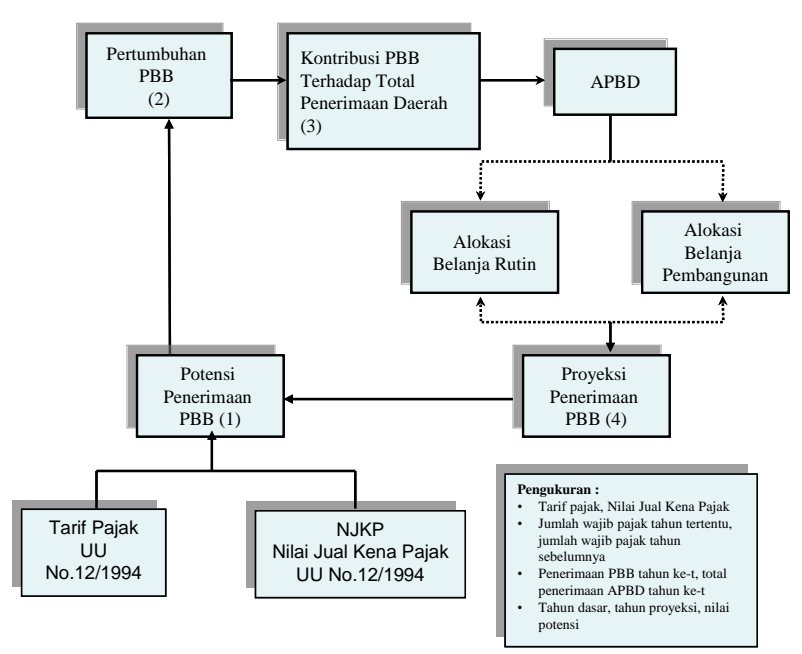

Gambar 4: Model Kerangka Kerja Potensi Penerimaan Pajak Bumi dan Bangunan Sektor Perdesaan Dan Perkotaan 


\section{Hasil Analisis Data dan Pembahasan}

\section{a. Analisis Pertumbuhan}

Berdasarkan rumus maka hasil perhitungan data yang diperoleh dari penelitian dapat dilihat pada (tabel 7) berikut ini:

Tabel 7 Pertumbuhan Penerimaan PBB Sektor Perdesaan dan Perkotaan di Kabupaten

Pati, 2000/2001-2005

\begin{tabular}{|c|c|c|c|c|}
\hline No & Tahun Anggaran & $\begin{array}{c}\text { Realisasi Penerimaan } \\
(\mathrm{Rp})\end{array}$ & $\begin{array}{c}\text { Pertumbuhan } \\
(\mathrm{Rp})\end{array}$ & $\begin{array}{c}\text { Pertumbuhan } \\
(\%)\end{array}$ \\
\hline 1 & $2000 / 2001$ & 4.582 .441 .614 & - & - \\
\hline 2 & $2001 / 2002$ & 4.090 .846 .794 & 491.594820 & -10.73 \\
\hline 3 & $2002 / 2003$ & 4.457 .582492 & 366.735 .698 & 8.96 \\
\hline 4 & $2003 / 2004$ & 4.604 .074150 & 746.91658 & 16,21 \\
\hline 5 & $2004 / 2005$ & 4.862 .216672 & 258.142522 & 5,61 \\
\hline \multicolumn{4}{|c|}{ Rata-rata } & 4,01 \\
\hline
\end{tabular}

Sumber: Kantor Dinas Pendapatan Kabupaten Pati, beberapa terbitan (data diolah)

Memperhatikan hasil analisis data pada tabel 7 tersebut, dimana pada tahun 2000/2001 ke 2001/2002 mengalami penurunan sebesar Rp491.594.820 atau turun sebesar $10,73 \%$, selanjutnya dari periode $2001 / 2002$ ke periode $2002 / 2003$ mengalami kenaikan sebesar Rp366.735.698. Namun pada periode 2002/2003 ke periode 2003/2004 mengalami kenaikan sebesar Rp746.491.658 atau naik sekitar 16,75\%, kemudian periode 2003/2004 ke periode 2004/2005 terjadi kenaikan kembali jumlah penerimaan sebesar Rp258.142.522 atau naik sebesar $5,61 \%$. Secara umum tingkat pertumbuhan penerimaan PBB sektor perdesaan dan perkotaan lima tahun terakhir mengalami Fluktuasi dengan rata-rata pertumbuhan 4,01\%, bahkan ada yang negatif ini terlihat pada dua periode pengamatan.

Demikian pula halnya dengan jumlah wajib pajak pada lima tahun terakhir juga mengalami Fluktuasi seperti yang terjadi pada periode 2000/2001 ke periode 2004/2005 mengalami kenaikan sekitar 6,14\%, kemudian periode 2000/2001 ke periode 2001/2002 mengalami penurunan sekitar 4,16\%. Selanjutnya periode 2002/2003 juga mengalami penurunan sekitar 5,01\% dan periode 2003/2004 ke periode 2004/2005 juga terjadi penurunan sekitar 4,98\%, seperti yang terlihat pada (tabel 8) berikut :

Tabel 8 Pertumbuhan wajib PBB Sektor Perdesaan dan Perkotaan di Kabupaten Pati, 2000/2001-2004/2005

\begin{tabular}{|c|c|c|c|c|}
\hline \multirow{2}{*}{ No } & \multirow{2}{*}{ Tahun Anggaran } & \multirow{2}{*}{$\begin{array}{l}\text { Wajib } \\
\text { Pajak }\end{array}$} & \multicolumn{2}{|c|}{ Pertumbuhan } \\
\cline { 4 - 5 } & & Jumlah Wajib Pajak & $\%$ \\
\hline 1 & $2000 / 2001$ & 619.364 & - & - \\
\hline 2 & $2001 / 2002$ & 639.295 & 9930 & 6,14 \\
\hline 3 & $2002 / 2003$ & 642.730 & 4.293 & 4,16 \\
\hline 4 & $2003 / 2004$ & 643.589 & 1.859 & 5,01 \\
\hline 5 & $2004 / 2005$ & 634.911 & -1.401 & 4,98 \\
\hline \multicolumn{3}{|c|}{ Rata-rata } & 4,20 \\
\hline
\end{tabular}

Sumber, KP-PBB Kabupaten Pati, beberapa terbitan (data diolah)

Terjadinya peningkatan ataupun penurunan penerimaan dan jumlah obyek pajak PBB sektor perdesaan dan perkotaan tergantung pada upaya yang dilakukan oleh Kantor Pelayanan PBB serta pemerintah daerah dalam mengadakan pendataan obyek pajak dan subyek PBB setiap periode tertentu. Perkembangan penerimaan PBB dan pertumbuhan wajib pajak akan terus meningkat apabila pendataan diadakan secara intensif dan cermat dilakukan minimal dua tahun sekali, dan sebaliknya apabila pada periode tertentu tidak diadakan pendataan memungkinkan terjadinya penurunan. 
Pendataan obyek dan subyek PBB tentu memerlukan suatu biaya yang cukup besar, waktu yang lama serta tenaga profesional yang memadai untuk menghasilkan data yang lebih baik, mengingat keterbatasan tersebut di atas maka pihak pemerintah daerah masih bersifat pasif untuk melakukan pendataan yang akurat sehingga masih ada lokasi yang belum terjangkau oleh petugas pendata dari pihak KP PBB.

Untuk meningkatkan penerimaan PBB sektor perdesaan dan perkotaan di Kabupaten Pati diperlukan -suatu pendataan obyek dan subyek PBB, maka pihak pemerintah daerah perlu merencanakan dan menganggarkan biaya pendataan PBB setiap tahunnya dan jangan hanya menunggu proyek yang datang dari pusat.

\section{b. Analisis Kontribusi}

Untuk mengetahui tingkat kontribusi penerimaan PBB sektor perdesaan dan perkotaan terhadap total penerimaan daerah (APBD) Kabupaten Pati dalam periode penelitian dapat dihitung sesuai dengan rumus yang tersebut pada alat analisis, hasilnya dapat dilihat pada (tabel 9) berikut ini:

Tabel 9 Kontribusi PBB Sektor Perdesaan dan Perkotaan Terhadap APBD

Kabupaten Pati, 2000/2001 - 2004/2005

\begin{tabular}{|c|c|c|c|c|}
\hline No & $\begin{array}{c}\text { Tahun } \\
\text { Anggaran }\end{array}$ & $\begin{array}{c}\text { Realisasi Penerimaan } \\
\text { PBB Sektor perdesaan } \\
\text { \& Perkotaan (Rp) }\end{array}$ & $\begin{array}{c}\text { Total Realisasi } \\
\text { Penerimaan Daerah } \\
\text { (APBD) (Rp) }\end{array}$ & $\begin{array}{c}\text { Kontribusi } \\
(\%)\end{array}$ \\
\hline 1 & $2000 / 2001$ & 4.582 .441 .614 & $107.195 .008 .956,98$ & 4,27 \\
\hline 2 & $2001 / 2002$ & 4.090 .846 .794 & $127.124 .813 .739,78$ & 3,22 \\
\hline 3 & $2002 / 2003$ & 4.457 .582 .492 & $153.074 .366 .740,75$ & 2,91 \\
\hline 4 & $2003 / 2004$ & 4.604 .074 .150 & $128.061 .43 .2 .623,96$ & 3,05 \\
\hline 5 & $2004 / 2005$ & 4.862 .216 .672 & $297.903 .538 .681,32$ & 1,63 \\
\hline \multicolumn{4}{|c|}{ Rata-rata } & 3,02 \\
\hline
\end{tabular}

Sumber : Kantor Dispenda, Bagian Keuangan Setda Kabupaten Pati, beberapa terbitan (data diolah)

Berdasarkan hasil perhitungan data pada tabel di atas terlihat bahwa kontribusi PBB sektor perdesaan dan perkotaan terhadap APBD Kabupaten Pati periode 2000/2001 hanya $4,27 \%$, kemudian periode 2001/2002 turun menjadi $3,22 \%$, selanjutnya pada periode 2002/2003 kontribusinya menurun kembali'menjadi 2,91\%. Namun pada periode 2003/2004 terjadi kenaikan sehingga kontribusinya mencapai 3,05\% dan selanjutnya pada periode 2004/2005 turun kembali menjadi 1,63\%.

Kontribusi PBB sektor perdesaan dan perkotaan terhadap APBD Kabupaten Pati selama periode penelitian hasilnya sangat berfluktuatif, kontribusi yang tertinggi terjadi pada periode 2000/2001 hal ini terjadi oleh karena penerimaan PBB sektor perdesaan dan perkotaan pada tahun anggaran tersebut meningkat sedangkan realisasi penerimaan APBD terjadi penurunan. Kemudian lain halnya pada periode 2004/2005 di mana kontribusi merupakan yang terendah pada periode penelitian yaitu berkisar $1,70 \%$ ini karena realisasi penerimaan PBB sektor perdesaan den perkotaan kenaikannya sangat kecil sedangkan realisasi penerimaan total APBD terjadi kenaikan yang cukup besar, hal ini disebabkan dimulainya penerapan otonomi daerah di mana lembaga vertikal menjadi dinas daerah.

\section{c. Analisis Proyeksi Penerimaan PBB}

Dengan berlakunya Undang-undang Nomor 12 tahun 1994 tentang Perubahan Undang-undang Nomor 12 tahun 1985 tentang Pajak Bumi dan Bangunan yang mulai berlaku tanggal 1 Januari 1995, untuk Kabupaten Pati cukup berpengaruh yakni terjadinya kenaikan terhadap penerimaan PBB khususnya sektor perdesaan, dan untuk NJOPTKP mulai 1 Januari 2004 sudah berubah dari Rp 8.000.000,- menjadi Rp12.000.000. 
Untuk melihat berapa proyeksi penerimaan PBB tahun 2000 dan tahun 2005 adalah: A. Proyeksi tahun ke-1 (2000). Proyeksi penerimaan PBB tahun 2005 diawali dengan estimasi dasar setiap variabel untuk mendapatkan perhitungan pendapatan satu tahun. Perhitungannya adalah:

1. Dari perhitungan potensi PBB tahun 2001 sebagai asumsi tahun berjalan adalah sebesar Rp7.565.837.558 yang terdiri dari sektor perdesaanRp6.E57,937.051 dan sektor perkotaan Rp907.900.506

2. Peningkatan cakupan

a) Penambahan subyek/obyek pajak, tidak ada.

b) Mengurangi tunggakan. Tunggakan tahun 2005 masing-masing sebesar 50\% dari Rp918.120.809 = Rp459,060.404 dan untuk sektor perkotaan $50 \%$ dari Rp106.782.213 = Rp53.391.106 dengan jumlah keseluruhan penerimaan dari tunggakan adalah Rp 512.451.510.

c) Pertumbuhan penduduk tetap sebesar $1,60 \%$ (diperoleh dari Pati dalam angka tahun 2004) menyebabkan jumlah penduduk bertambah dari 1.588.369 tahun 2004 bertambah sebanyak 25.413, 80\% adalah penduduk desa sebanyak 20.330 jiwa dan sisanya sebanyak 5.083 jiwa adalah penduduk perkotaan. Diasumsikan $0,5 \%$ dari pertambahan ini adalah wajib pajak PBB yang membayar masing-masing 1 obyek pajak sehingga perhitungannya adalah:
Sektor perdesaan 101 x Rp 5.000,-
$=\mathrm{Rp}$
13.417.800,-
Sektor perkotaan 25 x Rp 6.450,-
$=\mathrm{Rp}$ $1.536 .700,-$
14.954.500,-

Jumlah Sektor pedesaan dan perkotaan $=\mathrm{Rp}$

(lihat perhitungan hal 34, 43 dan 44)

d) Inflasi, diasumsikan masih tetap sebesar $6.21 \%$

Estimasi dasar,

Perdesaan, 6.21 \% dari Rp 6.657.937.051 = Rp 413.457.890

Perkotaan, 6.21\% dari Rp 907.900.506 = Rp 56.380.621

Cakupan 2.a (nihil)

Penduduk

Perdesaan, $6.21 \%$ dari 13.417.800,--

Perkotaan, $6.21 \%$ dan 1.536.700,- $\quad=\mathrm{Rp} \quad 833.245$

$\begin{array}{lll}\text { Total dari Inflasi } & =\mathrm{Rp} & 470.757 .185\end{array}$

Dan hasil perhitungan proyeksi, maka penerimaan PBB sektor perdesaan dan perkotaan tahun 2002 sebagai akibat adanya perubahan Nilai Jual Obyek Pajak Tidak Kena Pajak sebesar Rp12.000.000 secara rata-rata untuk sektor perdesaan mengalami peningkatan demikian juga terhadap sektor perkotaan. Karena Nilai Jual Obyek Pajak di kota obyek pajak yang kecil dapat ditutupi oleh nilai jual obyek pajak yang besar. Perhitungan proyeksi dimaksud dapat dilihat pada (tabel 10) berikut ini.

Tabel 10. Proyeksi PBB tahun 2005

\begin{tabular}{|c|c|c|c|}
\hline No & Variabel & & Nilai \\
\hline 1 & Estimasi Dasar & $\begin{array}{l}\text { Perdesaan } \\
\text { Perkotaan }\end{array}$ & $\begin{array}{r}6.657 .937 .051 \\
\\
7.507 .900 .506 \\
.565 .837 .558\end{array}$ \\
\hline 2 & Peningkatan Cakupan & $\begin{array}{l}\text { a) Obyek baru } \\
\text { b) Tunggakan }\end{array}$ & $\begin{array}{r}\text { Tidak ada } \\
512.451 .510\end{array}$ \\
\hline 3 & Pertumbuhan Penduduk & & 14.954 .500 \\
\hline 4 & Inflasi & \begin{tabular}{|l} 
Jumlah \\
Cadangan $10 \%$ \\
Proyeksi 2002
\end{tabular} & 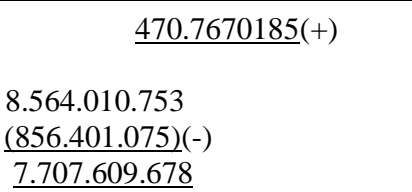 \\
\hline
\end{tabular}


B. Proyeksi tahun 2005. Asumsi proyeksi tahun ke-2 yang didasarkan pada proyeksi tahun 2005, perhitungannya adalah:

1. Perhitungan PBB sektor perdesaan adalah Rp7.536.329.462 dan sektor perkotaan adalah Rp1.027.681.290 dengan jumlah keseluruhan adalah Rp8.564.010.753

2.Tunggakan, diasumsikan tunggakan tahun 2000 sebesar Rp 600.000.000. Tunggakan ini terjadi karena adanya prosedur yang tidak berjalan dengan baik Setelah prosedur berjalan baik, tunggakan aapat diturunkan menjadi Rp350.000.000 pada akhir tahun 2005. Jadi ada penerimaan pajak sebesar Rp200.000:000 untuk sektor perdesaan dan Rp50.000.000 untuk sektor perkotaan;

3. Pertumbuhan penduduk diasumsikan tetap sebesar $1,60 \%$ menyebabkan jumlah penduduk bertambah dari 1.613 .782 tahun 2000 bertambah sebanyak $25.820,80 \%$ adalah penduduk desa sebanyak 20.656 jiwa dan sisanya sebanyak 5.164 jiwa adalah penduduk perkotaan. Diasumsikan sama dengan tahun sebelumnya $0,5 \%$ dari

pertambahan ini adalah wajib pajak PBB yang membayar masing-masing ?1 obyek pajak sehingga perhitungannya adalah:

Sektor perdesaan 203 x Rp 5.000;

$=\operatorname{Rp} 1.015 .000$

Sektor perkotaan 26 x Rp 6.450;

$=\operatorname{Rp} \quad 167.700$

Jumlah sektor perdesaan dan perkotaan

$=\operatorname{Rp} 1.182 .700$

4. Inflasi, diasumsikan masih tetap sebesar $6,21 \%$

a. Estimasi dasar.

1. Perdesaan, $6.21 \%$ dari Rp 7.536.329.462

2. Perkotaan, $6.21 \%$ dari Rp 1.027.681.290

$=\operatorname{Rp} 468.006 .059$

$=\operatorname{Rp} \quad 63.819 .008$

b. Cakupan 2.a (nihil)

c. Penduduk:

1. Perdesaan, 6;21 \% dari Rp 1.015 .000

2. Perkotaan, $6.21 \%$ dari Rp 167.700

$=\operatorname{Rp} 6.303 .150$

$=\mathrm{Rp} \quad 10.414$

Total dari inflasi $=\operatorname{Rp} 538.138 .631$

Dari hasil perhitungan proyeksi, maka penerimaan PBB sektor perdesaan dan perkotaan tahun 2005 dapat dilihat pada (tabel 11) berikut ini :

Tabel 11 Proyeksi PBB tahun 2005

\begin{tabular}{|c|l|lc|}
\hline No & \multicolumn{1}{|c|}{ Variabel } & \multicolumn{1}{|c|}{ Nilai } \\
\hline 1 & Estimasi Dasar. & Perdesaan & 7.536 .329 .462 \\
2 & Peningkatan Cakupan & Perkotaan & $\underline{1.027 .681 .290}$ \\
4 & Pertumbuhan Penduduk & a.564.010.753 \\
5 & Inflasi & a) Obyek baru & Tidak ada \\
& & b) Tunggakan & 250.000 .000 \\
& & & 1.182 .700 \\
& & & $538.138 .631(+)$ \\
& & Jumlah & 9.353 .332 .084 \\
& & Cadangan 10\% & $(935.333 .208)(-)$ \\
& & Proyeksi 2003 & 8,417998876 \\
\hline
\end{tabular}




\section{Kesimpulan dan Saran}

Dari hasil analisis dan pembahasan yang telah dikemukakan pada bab terdahulu dapat disimpulkan sebagai berikut.

1. Tingkat pertumbuhan penerimaan PBB sektor perdesaan dan perkotaan di Kabupaten Pati selama periode 2000/2001-2004/2005 berfluktuatif. Realisasi penerimaannya selalu tidak memenuhi target yang ditetapkan. Hal tersebut disebabkan karena diterimanya SPPT oleh wajib pajak selalu terlambat 6 bulan, sehingga keefektifan waktu untuk menagih pada wajib pajak terbatas hanya 6 bulan saja, selain hal tersebut tingkat pendidikan dan pengetahuan wajib pajak, yang sangat heterogen. Terlihat bahwa pada periode 2000-2004 mengalami penurunan dari tahun sebelumnya sebesar Rp491.594.820, atau turun sebesar 10,73\%, kemudian periode 2000/2001 mengalami kenaikan dari tahun sebelumnya sebesar Rp366.735.698 atau naik sebesar 8,96\%, pada periode 2004/2005 terjadi penurunan sebesar Rp146.491.658 atau berkurang 3,30\%, selanjutnya pada periode 2001/2002 terjadi kenaikan sebesar Rp258.142.522 atau naik 5,6\% sehingga rata-rata pertumbuhan se19ma periode pengamatan sebesar $1,78 \%$. Demikian pula halnya dengan wajib pajak yang juga mengalami fluktuatif dengan rata-rata pertumbuhan $0,50 \%$.

2. Kontribusi PBB sektor perdesaan dan perkotaan terhadap APBD dihitung dengan membandingkan total penerimaan $\mathrm{PBB}$ sektor perdesaan dan perkotaan, diperoleh bahwa pengaruh penerimaan $\mathrm{PBB}$ sektor perdesaan dan perkotaan selama periode pengamatan dengan tingkat rata-rata hanya mencapai 3,02\% per tahunnya. Hal ini menunjukkan bahwa penerimaan PBB sektor perdesaan dan perkotaan masih sangat kecil pengaruhnya terhadap total penerimaan daerah (APBD) Kabupaten Pati.

3. Hasil perhitungan proyeksi dengan metode faktorial menunjukkan bahwa prospek penerimaan PBB sektor perdesaan dan perkotaan di Kabupaten Pati memperlihatkan angka yang meningkat. Pada prediksi ke I tahun 2005 sebesar Rp8.564.010.753, dan untuk prediksi ke 2 tahun 2003 sebesar Rp9.353.332.084 atau meningkat 9\% dan pada periode sebelumnya yaitu tahun 2001 sebesar Rp 7.565.837.558 ke tahun 2002 sebesar Rp8.564.010.753 atau ada kenaikan sebesar 13\%. Hasil prediksi tersebut masih dapat bertambah apabila pendataan dan pemutakhiran data obyek dan subyek pajak dilakukan secara akurat, penyuluhan terus. digiatkan, sumber daya manusia pengelola dikembangkan dan koordinasi berjalan dengan baik.

Berdasarkan uraian yang telah dikemukakan dalam kesimpulan dapat diajukan saran-saran sebagai berikut.

1. Selama ini baik KP PBB, Dipenda, Camat, Lurah/kepala Desa belum pernah memberikan penyuluhan tentang klasifikasi, tarif, NJOP dan NJOPTKP, sehingga setiap ada kenaikan selalu dirasakan berat oleh wajib pajak. Disarankan apabila pada tahun depan akan ada kenaikan, maka satu tahun sebelumnya harus sudah ada Pemberitahuan Terlebih dahulu, informasi yang efektif Bisa melalui SPPT, dan SPPT diupayakan sudah dapat diterima wajib pajak pada setiap bulan Januari, sehingga petugas pemungut memiliki waktu kerja yang cukup.

2. Nilai Jual Kena Pajak sebesar $20 \%$ akan berpengaruh terhadap potensi PBB meskipun demikian untuk masing-masing wilayah dan kelas obyek pajak …1-. beda. Apabila NJKP akan dinaikkan maka disarankan untuk ditetapkan sec beragam, hal ini berkaitan dengan status PBB sebagai penerimaan daerah.

\section{Daftar Pustaka}

Insukindro, et.al. , 1994, Evaluasi Terhadap Penentuan Tarif, NJKP, NJOP TKP dan Peningkatan Efektivitas Pemungutan PBB Kerja sama PAU SE UGM dengan Dirjen Pajak Depke, PAU SE UGM, Yogyakarta. 
Kaho, Riwu, Yosep, 1988, Prospek Otonomi Daerah di Negara Republik Indonesia, Fisifol UGM, Yogyakarta.

Mardiasmo dan Makhfatih, 2000, "Penghitungan Potensi Pajak dan Retribusi Daerah di Kabupaten Magelang", Laporan Akhir.

Munawir, 1997, Perpajakan, Edisi Kelima. Liberty, Yogyakarta.

Republik Indonesia,1999. Undang-undang Otonomi Daerah, Biro Bina Otonomi Daerah Sekretariat Wilayah/Daerah Tingkat I Sulawesi Selatan.

Sidik, Machfud, 1996: "Pajak dan Retribusi Peranan dan Permasalahan" Bahan Kuliah pada Sekolah Staf dan Komando-TNI AL, Jakarta.

Sinar Grafika, 2000. Seri Perpajakan PBB, Jakarta.

Sjoquist. David L, and Mary, B.W. 2000. "Economies of Scale In Property "Tax Assessment". National Tax Journal. Vol. 52. Iss. 2, Juni, P:207-2?0.

Soediyono, R, . 1992, Ekonomi Makro: Pengantar Analisis Pendapatan Nasional Cetakan ke II, Liberty, Yogyakarta.

Suparmoko, M. 1994. Keuangan Negara Dalam Teori dan Praktek, Edisi Empat, BPFEYogyakarta.

Widodo Triyanto,1990, Indikator, Ekonomi, Dasar Perhitungan Perekonomian Di Indonesia. Penerbit Kanisius, Yogyakarta. 